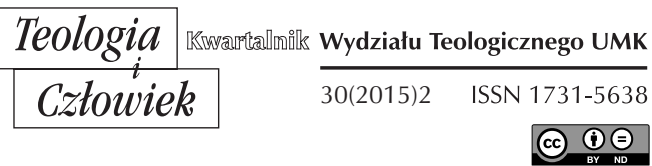

KS. SŁAWOMIR TYKARSKI*

TORUŃ

\title{
NEGOCJACJE JAKO SPOSÓB ROZWIAZZYWANIA KONFLIKTÓW MAŁŻEŃSKICH I RODZINNYCH
}

DOI: http://dx.doi.org/10.12775/TiCz.2015.026

Konflikt jest zjawiskiem, które występuje w każdej grupie społecznej. Nie omija on również małżeństwa i rodziny. W życiu małżeńsko-rodzinnym jest on o tyle istotny, że ze względu na silne relacje emocjonalne może być przyczyną powstawania zranień, zniszczenia więzi uczuciowych oraz zaburzeń komunikacji wewnątrzrodzinnej między osobami. Skuteczną pomocą w rozwiązywaniu konfliktów powstających między małżonkami bądź członkami rodziny mogą być negocjacje. Zapoznanie się z ich przebiegiem, wytycznymi w ich prowadzeniu oraz zasadami poprawnej komunikacji stanowi skuteczne narzędzie $\mathrm{w}$ konstruktywnym rozwiązaniu sporu.

\section{NATURA KONFLIKTU I JEGO RODZAJE}

Słowo konflikt pochodzi od łacińskiego conductus i oznacza tyle co zderzenie. Można je rozumieć jako kolizję wykluczających się celów,

* Ks. Sławomir Tykarski - kapłan diecezji toruńskiej, dr teologii pastoralnej, psychoterapeuta, wykładowca na Wydziale Teologicznym UMK na kierunku nauki o rodzinie. Specjalizuje się w psychoterapii par i małżeństw. Udziela pomocy małżonkom przeżywającym kryzys swojego związku. 
interesów, postaw przynajmniej dwóch stron. „Można mówić o konflikcie w momencie, gdy różnice między ludźmi wzajemnie od siebie zależnymi uznawane są za ograniczające i zagrażające potrzebom i interesom jednostki oraz kiedy dochodzi do napięcia i intensyfikacji uczuć, ponieważ jedna ze stron ma wrażenie, że jej oponent wykorzystuje swoją siłę, by wpłynąć na sytuację i zmienić ją na swoją korzyść" ${ }^{1}$. Sytuacja konfliktowa niejednokrotnie występuje w życiu małżeńskim bądź rodzinnym, kiedy małżonkowie jako strony stają na stanowiskach opozycyjnych - ich wzajemne cele, potrzeby lub życzenia się wykluczają, a interesy nie są zbieżne. Podobna sytuacja może zdarzyć się również pomiędzy innymi członkami rodziny, na przykład między teściami a jednym z małżonków.

Niezmiernie ważny jest fakt uświadomienia sobie, że to wcale nie różnice międzyludzkie są źródłem konfliktu, ale to, w jaki sposób osoby chcą go rozwiązać i jak traktują kwestie problematyczne. W sytuacji małżeńsko-rodzinnej ważną rolę w konflikcie odgrywa zależność. Okazuje się, że zachodzi korelacja pomiędzy stopniem zażyłości w relacji a prawdopodobieństwem pojawienia się konfliktu - im strony są bardziej od siebie zależne, tym możliwość zaistnienia konfliktu wzrasta.

Warto w tym miejscu przytoczyć kategoryzację konfliktów, jaką proponuje Nordhelle. Wyróżnia ona konflikty interesów, wartości, konflikty instrumentalne oraz pseudokonflikty². Znajomość kategorii konfliktów jest istotna, gdyż pozwoli uświadomić stronom, czego dotyczy spór.

Konflikt interesów zachodzi w sytuacji braku określonych dóbr (np. pieniędzy, czasu), na których zależy osobom skonfliktowanym, roszczącym sobie pretensje do ich posiadania. Inne rodzaje konfliktów, opartych na interesach, dotyczą potrzeb, wśród których można wyróżnić fizyczne (np. potrzeba jedzenia, posiadania ubrań) i psychiczne (np. poczucie bezpieczeństwa ekonomicznego, socjalnego, poczucie uznania, docenienia, samorealizacji) oraz życzeń.

Konflikt wartości, jak wskazuje nazwa, dotyczy wartości wyznawanych przez człowieka. Mogą mieć one charakter moralny, etyczny, społeczny, religijny czy psychologiczny. Odgrywają one istotną rolę, ponieważ są

${ }^{1}$ G. Nordhelle, Mediacja. Sztuka rozwiązywania konfliktów, Gdańsk 2010, s. 26.

2 Zob. tamże, s. 52-64; C.W. Moore, Mediacje. Praktyczne strategie rozwiązywania konfliktów, Warszawa 2009, s. 76; K. Bargiel-Matusiewicz, Negocjacje i mediacje, Warszawa 2010, s. 38-39. 
wyznacznikiem ludzkich działań i wyborów. Warto zaznaczyć, że wartości same w sobie nie są przyczyną konfliktów. Osoby, które nie wyznają tych samych wartości, mogą przecież siebie szanować i koegzystować. Problem zachodzi w przypadku, gdy strony nie akceptują różnic wartości, co może stać się powodem poważnego sporu. W życiu małżeńskim mogą to być różnice w praktykowaniu religii i moralności z nią związanej (np. wychowywanie potomstwa w wierze, pożycia seksualnego, stosowania środków antykoncepcyjnych). Należy zaznaczyć, że niekiedy negocjacje w przypadku konfliktu wartości nie są w ogóle możliwe lub bardzo trudne do przeprowadzenia, gdyż zazwyczaj ludzie bardzo niechętnie rezygnują ze swoich wartości. Poprowadzenie negocjacji przez małżonków jest możliwe w przypadku zamiany wartości na interesy, życzenia bądź potrzeby.

Konflikty instrumentalne dotyczą tego, co i w jaki sposób należy zrobić. Inaczej można je nazwać konfliktami proceduralnymi. Przykładem konfliktu instrumentalnego może być łamanie zasad nieprowadzenia kłótni małżonków przy dzieciach lub w gronie rodziny czy znajomych, niepodejmowanie ważnych tematów $\mathrm{w}$ chwilach zmęczenia bądź podczas pracy. Spory tego rodzaju można w pomyślny i dość łatwy sposób rozwiązać poprzez negocjacje.

Pseudokonflikty to sytuacje, w których małżonkowie czują, że są w stanie konfliktu, ale w rzeczywistości tak nie jest. Przyczyną takiego stanu rzeczy jest bardzo często wadliwa, niejasna bądź niepełna komunikacja. Innym źródłem pseudokonfliktu jest różnorodność rozumienia i interpretacji danej sytuacji przez strony. Powstaje wówczas następująca zależność: im gorsza jest jakość komunikacji, tym większe prawdopodobieństwo zaistnienia błędnej interpretacji. Należy zaznaczyć, że większość pseudokonfliktów to zwykłe nieporozumienia, do których dochodzi przez zaburzoną komunikację. W takiej sytuacji małżonkowie winni nauczyć się zasad prowadzenia rozmów, a także jak najczęściej prowadzić ze sobą dialog, informując się wzajemnie o własnych intencjach, emocjach, uczuciach i poglądach.

\section{RODZAJE CELÓW W KONFLIKCIE}

Niekiedy podczas konfliktu małżonkowie są przekonani, że kłócą się z konkretnego powodu, który potrafią nazwać. Patrząc jednak głębiej, okazuje się, iż konflikt wcale nie dotyczy tego, o czym byli przekonani, ale 
zupełnie czegoś innego. Stąd w konflikcie można wyróżnić cztery rodzaje celów: przedmiot konfliktu, relacje, tożsamość (własny wizerunek) oraz procedura $^{3}$.

Cele przedmiotowe odnoszą się do tego, czego chcą strony (co zrobić, gdzie pójść, jaką decyzję podjąć), dlatego łatwo je dostrzec, wyodrębnić i o nich rozmawiać. Można wyróżnić dwa rodzaje celów przedmiotowych: pierwszy, gdy osoby chcą odmiennych rzeczy, drugi, gdy ludzie chcą tego samego w przekonaniu o niewystarczalności zasobów.

W celach związanych z relacjami konflikt skupia się na pytaniu: „Kim dla siebie jesteśmy w naszej interakcji?”. W tego rodzaju celach małżonkowie określają, jak chcą być przez siebie traktowani, jakiej współzależności pragną (np. szacunku, szczerości, wsparcia, przyjaźni, życia bez tajemnic). Można wyodrębnić reguły dotyczące celów przedmiotowych i celów związanych z relacjami:

- „Każde stwierdzenie zawiera jakąś informację na temat relacji.

- Każdy odmiennie tłumaczy sobie i interpretuje informacje o relacjach.

- Cele związane z relacjami wiążą się z większym zaniepokojeniem niż cele przedmiotowe.

- Nasze cele związane z relacjami pojawiają się w reakcji na zachowanie drugiej osoby"4.

W celach związanych z tożsamością istotną rolę odgrywa zachowanie własnego wizerunku, czyli mówiąc potocznie zachowanie twarzy. Kiedy narasta konflikt, małżonkowie zachowanie twarzy (swojej godności) uznają za cel nadrzędny. Zwroty typu: „Jak ty mnie traktujesz?”, „Nie pozwolę, byś się do mnie odzywał w taki sposób” to przykłady wypowiedzi mających chronić wizerunek osoby. Wówczas kłótnia tak naprawdę nie dotyczy jakiegoś celu przedmiotowego, ale właśnie związanego z tożsamością. Niestety często małżonkowie nie zdają sobie z tego sprawy. Co więcej, zdarza się, że w obronie własnej godności uderzają w poczucie godności swojego rozmówcy, co eskaluje konflikt i prowadzi do zranień emocjonalnych. Remedium na taki stan jest podjęcie starań o przywróce-

${ }^{3}$ Zob. W.W. Wilmot, J.L. Hocker, Konflikty między ludźmi, Warszawa 2011, s. 105.

4 Tamże, s. 112. 
nie poczucia godności i wartości współmałżonka oraz odbudowanie jego wizerunku w oczach rozmówcy.

Ostatnim rodzajem celów w konflikcie są cele związane z procedurą. Podobnie jak w przypadku celów przedmiotowych są one łatwe do określenia i wyodrębnienia. Małżonkowie kłócą się o to, w jaki sposób formalnie lub nieformalnie pokierować konfliktem. Przykładem procedury może być umowa między małżonkami, że podczas kłótni nie podnoszą na siebie głosu, nie używają obraźliwych słów, nie przerywają sobie w wypowiedziach, nie doprowadzają do tak zwanych „cichych dni”. Zaostrzenie kłótni może być zintensyfikowane przez nieprzestrzeganie przyjętych reguł lub może przesunąć spór z celów przedmiotowych, relacyjnych na proceduralne. Wówczas następuje chaos - często małżonkowie nie wiedzą już, o co się kłócą i jak to przerwać. Potrzebna jest zatem świadomość celów, które podczas sporu mogą się w dość dynamiczny sposób zmieniać.

Warto w tym miejscu poruszyć kwestię przenikania się wyżej wymienionych celów. Oczywiście nie wszystkie rodzaje pojawiają się w każdym sporze. Może się jednak zdarzyć, że początkowy cel kłótni, którym był np. cel przedmiotowy, w trakcie sporu traci na znaczeniu na rzecz celu związanego z tożsamością, relacją bądź procedurą. Trzeba zaznaczyć, iż nieporozumienia związane z tożsamością bądź relacjami wzmacniają konflikt, leżąc u podstaw spraw przedmiotowych i proceduralnych. Dlatego skłóceni małżonkowie nie powinni koncentrować się tylko na jednym rodzaju celu, ale zastanowić się, czy nie ma jeszcze innych, których nie dostrzegali, a o które tak naprawdę się poróżnili. Zobrazowaniem tego niech będzie poniższy przykład:

Mąż poinformował żonę, że jego rodzice zapraszają ich na niedzielny obiad. Zrobił to, będąc w pracy, za pomocą wiadomości wysłanej przez internet. Żona, odpisując, powiedziała, że porozmawiają o tym w domu. Po powrocie mąż jednak nie nawiązał do tematu. Żona go również nie chciała podjąć tematu, gdyż uważała, że powinien to uczynić współmałżonek, bo od niego wyszła propozycja. Minęły dwa dni i mąż musiał dać odpowiedź swoich rodzicom, czy pojawią się na niedzielnym obiedzie. Nie konsultując się z żoną, potwierdził wspólne przybycie. Wieczorem tego dnia oznajmił to żonie, która zdenerwowała się, że podjął decyzję bez jej zgody, co stało się powodem kłótni. 
Analizując tę krótką historię, można zauważyć cele konfliktu. Na pierwszy plan wysuwa się cel proceduralny. Ma on kilka odsłon. Pierwsza dotyczy sposobu komunikacji. Temat wspólnego wyjścia na rodzinny obiad jest tematem poważnym i nie należałoby go rozwiązywać za pomocą wiadomości elektronicznych, lecz podczas osobistego spotkania. Ponadto według procedury żony to mąż winien $\mathrm{w}$ domu ponownie podjąć temat obiadu u teściów, czego nie zrobił (może nie ze złej woli, ale z braku wiedzy na temat procedury żony). Kolejna złamana procedura dotyczyła podejmowania przez męża samowolnej decyzji, która mogłaby brzmieć: „O wspólnych wyjściach decydujemy wspólnie”. Przyglądając się bliżej temu konfliktowi, można jednak dostrzec pojawienie się celu związanego z zachowaniem twarzy. Żonę zabolało to, że mąż podjął decyzję bez konsultacji. Poczuła się zlekceważona, co zaostrzyło konflikt między nimi. W ten sposób cel przedmiotowy, którym było wyjście na obiad do teściów, przerodził się w cel proceduralny i tożsamościowy. Ponadto po wspólnej rozmowie małżonków okazało się, że żona czuła opór przed obiadem rodzinnym, gdyż irytowała ją postawa teściów, którzy wciąż chwalą swojego syna, ukazując, jakie to szczęście ją spotkało, że ma tak wspaniałego męża. Żona jednak wie o zachowaniu męża z przeszłości, które ją bardzo zraniło do tego stopnia, że mogło zakończyć się rozpadem związku, o czym nie wiedzą teściowie. Dochodzi tu do celu relacyjnego - żona nie wie, na ile jest ważna dla swojego męża, ma zachwiane poczucie wartości, nie czuje się dla niego na tyle ważna, na ile chciałaby być. Prowadzi to do konfliktów między nimi. Można dostrzec, że cel przedmiotowy i cele proceduralne, choć najbardziej widoczne, wcale nie są najistotniejsze $\mathrm{w}$ tym sporze. $\mathrm{O}$ wiele ważniejsze są cele związane $\mathrm{z}$ tożsamością i relacją. Trudność polega na braku świadomości, że one występują, jeśli małżonkowie nie zaczną o nich mówić. Dlatego tak bardzo ważna jest wspólna i szczera rozmowa na temat celów w sporach, które występują między nimi, wyraźnie określone cele są bowiem częściej osiągalne niż niejasne i mgliste. Ponadto trudno dojść do porozumienia i rozwiązania sporu, jeśli strony nie wiedzą, czego tak naprawdę chcą. W opisanym wyżej przypadku żonie bardziej chodziło o cele związane z tożsamością i relacją niż z przestrzeganiem celów proceduralnych. 


\section{STYLE REAGOWANIA W KONFLIKCIE}

Każdy człowiek w sytuacjach konfliktowych świadomie bądź nie przyjmuje pewną taktykę, strategię, według której postępuje. Style w konflikcie to wzorce reakcji wykorzystywane w sytuacjach spornych. Kilmann i Thomas wyróżniają pięć stylów: współpraca, przystosowanie, rywalizacja, unikanie, kompromis ${ }^{5}$. Przedstawia to poniższy schemat:

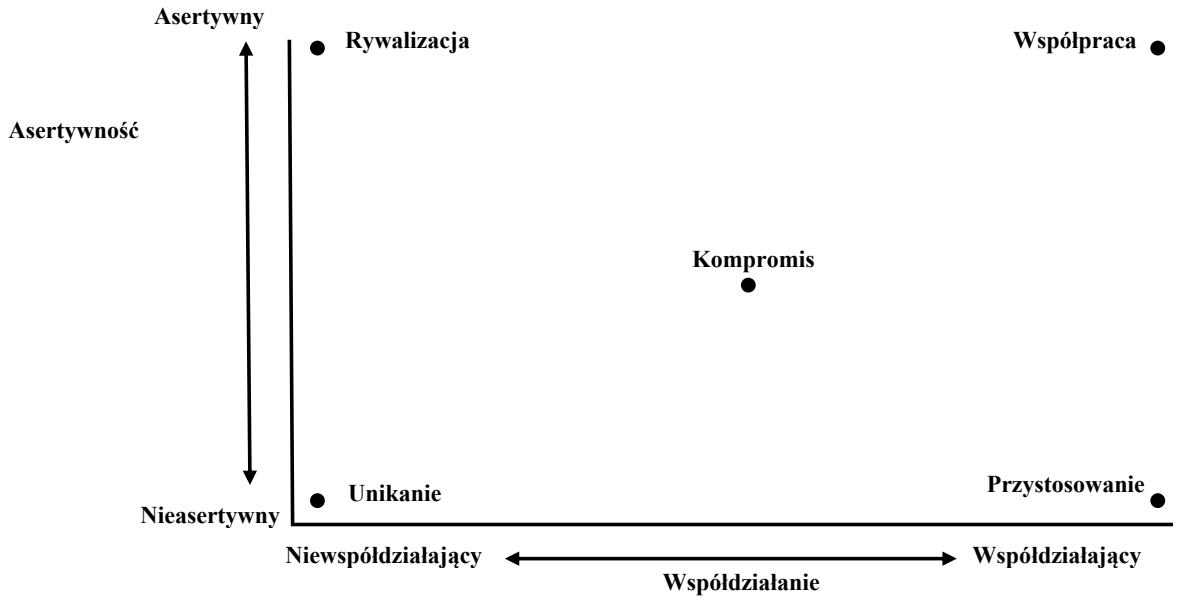

Źródło: W.W. Wilmot, J.L. Hocker, Konflikty między ludźmi, Warszawa 2011, s. 193.

Przyjęte style reagowania w sytuacjach konfliktowych nie zawsze muszą być takie same, przyjmując sztywny charakter. Niekiedy osoby muszą wybierać, co będzie lepsze: wycofać się i chronić czy angażować się i rywalizować. Wiąże się to z poziomem asertywności w stosunku do chęci współpracy (współdziałania) i wagi relacji. Inaczej mówiąc, asertywność to troska o zadanie, a współpraca to wyznacznik troski o relacje. Można to przedstawić za pomocą schematu:

Osoby, którym nie zależy na relacji, lecz na wykonaniu zadania, będą posługiwać się stylem rywalizacji (zarządzania). Jednostki, którym nie zależy ani na zadaniu, ani na relacjach z drugą stroną, będą unikać konfliktu. Ci, dla których wspólne cele nie są aż tak ważne, za to istotne są

${ }^{5}$ R. Kilmann, K.W. Thomas, Interpersonal conflict-handling behavior as reflections of Jungian personality dimensions, „Psychological Reports”, 37(1975), s. 971-980. 


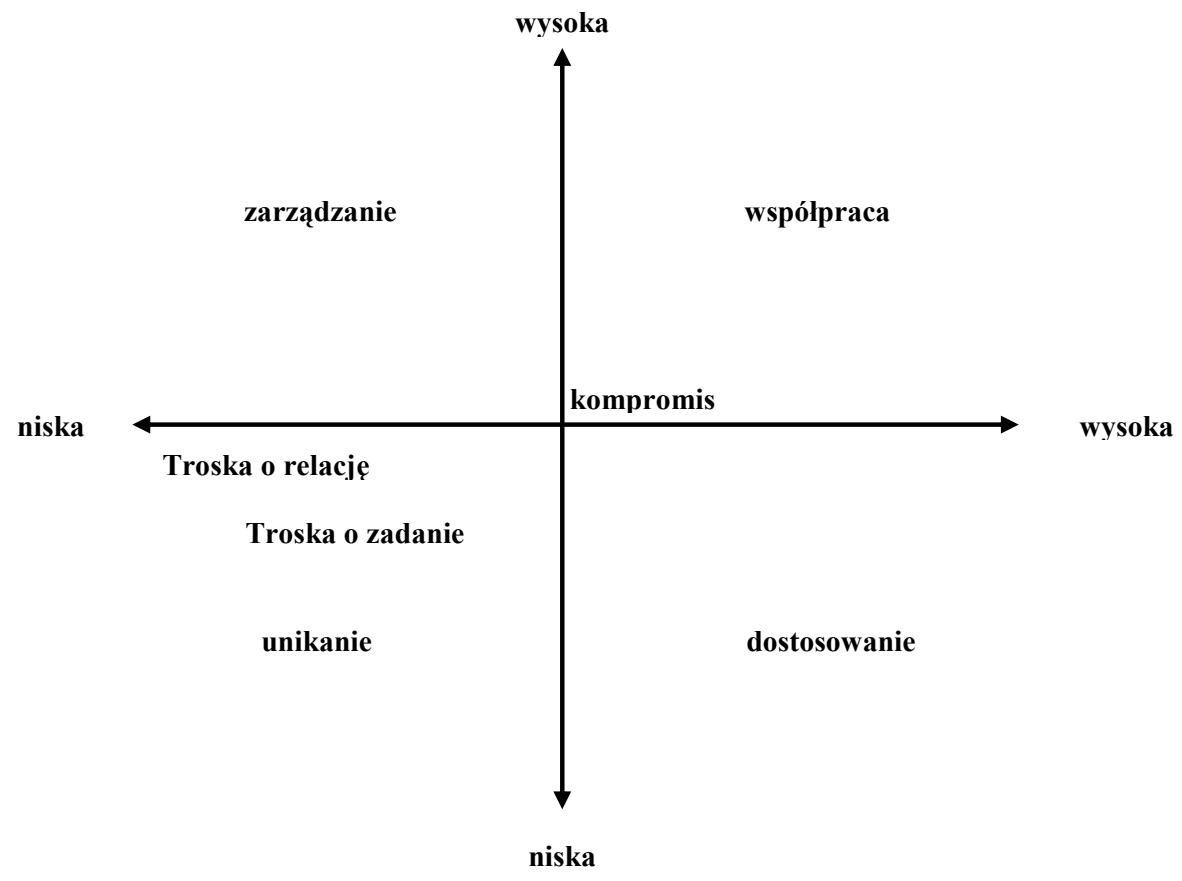

Źródło: S. Savage, E. Boyd-MacMillan, Konflikt w relacjach. Zrozumieć i przezwyciężyć, Poznań 2012, s. 121.

relacje, będą się przystosowywali (dostosowywali) do wymogów sytuacji. Natomiast osoby, którym zależy mocno zarówno na wspólnych celach, jak i na jakości relacji, będą współpracowały. Z kolei osoby korzystające z kompromisu charakteryzują się średnim poziomem troski zarówno o relacje, jak i o wykonywanie zadania. Pomocą w rozpoznaniu, którą strategią posługuje się osoba w sytuacji konfliktu, mogą być następujące pytania: „Czy kiedy jestem zdenerwowany, to staram się o to, by zadanie zostało wykonane po mojej myśli? (zarządzanie); Czy kiedy jestem zdenerwowany, wycofuję się, zmieniam temat i odwracam uwagę? (unikanie); Czy kiedy jestem zdenerwowany, mówię wprost i staram się uzyskać twórcze rozwiązanie? (współpraca); Czy kiedy jestem zdenerwowany, przestaję być bezpośredni i staram się utwierdzić relację? (dostosowanie); Czy kiedy jestem zdenerwowany, staram się postępować fair? (kompromis)”6.

${ }^{6}$ S. Savage, E. Boyd-MacMillan, Konflikt w relacjach. Zrozumieć i przezwyciężyć, Poznań 2012, s. 122. 
Należy zaznaczyć, że każda strategia stosowana w konflikcie ma swoje plusy i minusy ${ }^{7}$. Nie zawsze jedna strategia jest optymalna dla każdego rodzaju konfliktu. Wybór konkretnego stylu zależy od przedmiotu konfliktu oraz od jakości relacji z oponentem ${ }^{8}$. Rozważając jednak sytuację małżeńską, najlepszą metodą rozwiązywania konfliktów będzie współpraca (a nie kompromis, jak zwykło się potocznie uważać), małżonkom bowiem winno zależeć na realizacji wspólnych celów, jak i na głębi relacji. Ponadto współpraca pobudza kreatywność stron, daje poczucie emocjonalnej bliskości, zadowolenia, satysfakcji z rozwiązanego problemu, wzmacnia poczucie własnej wartości, uczy nowych kompetencji (np. w zakresie komunikacji), powiększa zaufanie partnerów, obniża napięcie powstałe w wyniku konfliktu9 ${ }^{9}$ Ze względu na znaczenie więzi małżeńskiej można rozważyć również stosowanie kompromisu i przystosowania. Kompromis umożliwia małżonkom osiągnięcie porozumienia przy mniejszym nakładzie czasu niż przy współpracy, a także daje poczucie równowagi sił (władzy). Natomiast przystosowanie sprawdzi się w sytuacji, gdy kwestia jest ważna dla jednej osoby, a nie ma większego znaczenia dla drugiej. Strategia ta chroni również przed wzajemnym skrzywdzeniem siebie czy wyrządzeniem przykrości. Natomiast z całą pewnością można powiedzieć, że rywalizacja (zarządzanie partnerem) i unikanie konfliktu nie wpływa dobroczynnie na kondycję małżeństwa. Rywalizacja może zaszkodzić małżonkom, osoby koncentrują się bowiem tylko na własnych celach, pomijając cele i potrzeby drugiej strony, co może być dla niej komunikatem, że się nie liczy w związku. W ten sposób kształtuje się relacja na poziomie wygrany-przegrany (zob. schemat poniżej), a przecież istota rozwiązania konfliktu w małżeństwie polega na tym, by małżonkowie byli wspólnie wygranymi. Ponadto rywalizacja może rodzić agresję (słowną lub fizyczną), chęć dominacji i nadużywanie władzy, wzmocnić poczu-

$7 \mathrm{Na}$ temat pozytywnych i negatywnych stron poszczególnych strategii w konflikcie zob. W.W. Wilmot, J.L. Hocker, dz. cyt., Warszawa 2011, s. 202, 210, 224-225, 226-227, 231.

${ }^{8}$ Więcej na temat przydatności konkretnych strategii w sytuacji konfliktu interpersonalnego zob. R.J. Lewicki, B. Barry, D. M. Saunders, Zasady negocjacji, Poznań 2012, s. 44.

9 Zob. S. Byra, Konflikt interpersonalny - istota i funkcje, w: A. Lewicka (red.), Profesjonalny mediator. Zostań nim. Poradnik metodyczny, Lublin 2008, s. 179-181. 
cie bezradności, poczucie skrzywdzenia, wyczerpania emocjonalnego, utrudnić komunikację ${ }^{10}$. Natomiast stosując strategie uniku, małżonkowie mogą doprowadzić do eskalacji konfliktu, który - wcześniej nierozwiązany - będzie przybierał na sile. Unikanie zatem nie jest właściwą strategią w małżeńskich sprzeczkach. Jak wskazują badania, małżonkowie, którzy w pierwszym roku małżeństwa byli zdania, że należy unikać konfliktów, deklarowali także niższy poziom poczucia szczęścia w pierwszych trzech latach trwania swojego związku od tych par, które uważały, że konfliktów nie należy unikać, ale je wspólnie rozwiązywać ${ }^{11}$.

Warto w tym miejscu przedstawić koncepcję Moore’a, który wyróżnia cztery możliwe wyniki sporu między stronami. Graficznie można to zilustrować w następujący sposób:

Wynik typu „wygrany-przegrany” widoczny jest w lewym, górnym rogu i prawym dolnym rogu wykresu. Charakterystycznymi cechami tego rodzaju zakończenia konfliktu są:

- „jedna ze stron dysponuje przytłaczającą przewagą siły,

- przyszłe relacje nie mają większego znaczenia,

- pula wygranych jest wysoka,

- jedna ze stron jest skrajnie asertywna, a druga pasywna lub nie tak agresywna jak »wygrany«,

- zaspokojenie interesów uczestników nie zależy od wzajemnej współpracy,

- jedna lub kilka stron nie chce współpracować i nie ma woli zaangażowania się w negocjacje oparte na kooperatywnym rozwiązaniu problemów, pozwalającym na obustronne zaspokojenie interesów.

Wyniki definiowane jako impas zaprezentowane zostały w dolnym lewym rogu. Takie rezultaty występują wtedy, gdy strony nie są w stanie dojść do porozumienia i gdy:

- obie strony z jakichkolwiek powodów zdecydowały się na unikanie konfliktu,

10 Tamże, s. 181-182.

11 Zob. S.E. Crohan, Marital happiness and spousal consensus on beliefs about marital conflict: A longitudinal investigation, „Journal of Social and Personal Relationships" 9(1992), s. 89-102. 
Stopień zaspokojenia interesów

Strony A (na przyklad żony)

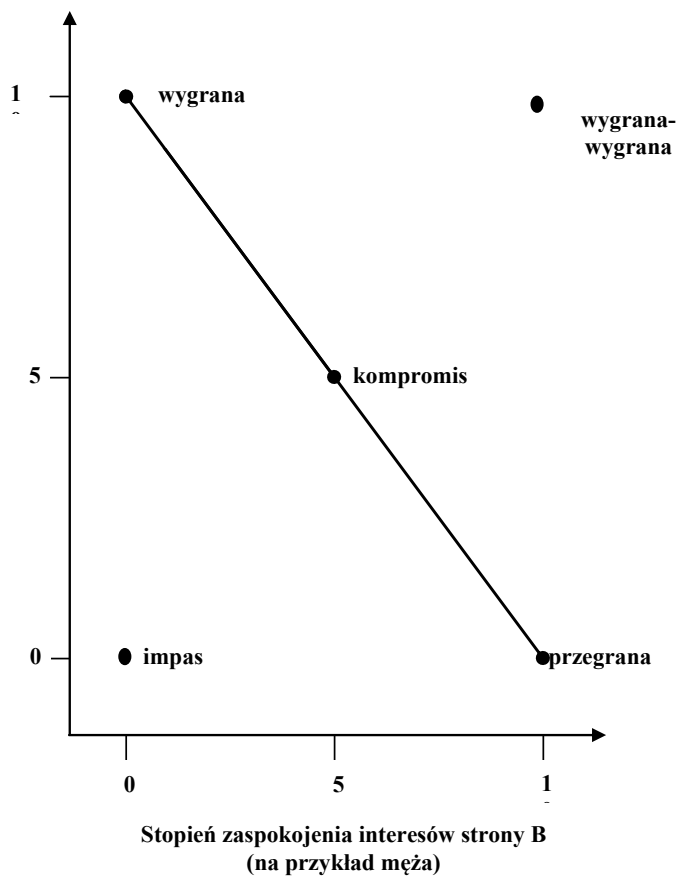

Źródło: C.W. Moore, Mediacje. Praktyczne strategie rozwiązywania konfliktów, Warszawa 2009, s. 115.

- żadna ze stron nie ma na tyle siły, by przeforsować jakieś rozwiązanie,

- relacji towarzyszy brak zaufania, kiepska komunikacja, intensywne emocje lub nieodpowiednia procedura rozwiązywania konfliktu,

- pula wygranych jest niska lub spór nie jest istotny dla żadnej ze stron,

- interesy stron nie są ze sobą powiązane,

- jedna lub kilka stron nie ma woli współpracy.

Wyniki w postaci kompromisu są pokazane na środku ukośnej linii. Rezultaty tego typu pojawiają się wówczas, gdy wszystkie strony rezygnują z części swoich celów po to, by zrealizować pozostałe. Mogą się one pojawić, gdy: 
- żadna ze stron nie ma na tyle siły, by zapewnić sobie całkowite zwycięstwo,

- przyszłe pozytywne relacje są dla uczestników istotne, ale nie ufają sobie na tyle, by pracować razem nad obopólnie korzystnymi rozwiązaniami integratywnymi,

- pula wygranych jest umiarkowanie wysoka,

- obie strony są asertywne,

- interesy obu stron są współzależne,

- strony mają pewną swobodę działania w zakresie kooperacji, pertraktacji i rozwiązań kompromisowych.

Rozwiązania typu »wygrany-wygrany « mają miejsce wówczas, gdy wszystkie strony mają poczucie, że ich interesy zostały zaspokojone. Wynikom »wygrany-wygrany« sprzyjają następujące okoliczności:

- żadna ze stron nie angażuje się w próbę sił,

- istotne są dobre wzajemne relacje na przyszłość,

- wysoka stawka zachęca do wypracowania obustronnie satysfakcjonujących rozwiązań,

- obie strony są asertywnymi poszukiwaczami rozwiązań,

- interesy wszystkich uczestników są współzależne,

- strony mają wolność podejmowania współpracy oraz angażowania się we wspólne rozwiązywanie problemów"12.

Według koncepcji Moore’a najbardziej pożądanym wynikiem sporu w małżeństwie jest typ wygrany-wygrany. W zależności od poziomu wagi problemu sprawdzi się również kompromis.

\section{NEGOCJACJE - ETAPY I ZASADY PROWADZENIA}

Druga część niniejszego artykułu dotyczy negocjacji jako sposobu rozwiązywania konfliktów małżeńskich lub rodzinnych. Negocjacjami można nazwać dwustronny proces komunikacji, którego celem jest osiągnięcie porozumienia, gdy przynajmniej jedna ze stron nie zgadza się $\mathrm{z}$ danym rozwiązaniem sytuacji konfliktowej.

${ }^{12}$ C.W. Moore, dz. cyt., s. 114-116. 
Negocjacje można podzielić dwojako - na konfrontacyjne i integrujące, zwane także negocjacjami współpracy (kooperacji) ${ }^{13}$. Podstawowa różnica między nimi polega na sposobie rozwiązania konfliktu. W negocjacjach konfrontacyjnych strony podchodzą do sporu na poziomie wygrany-przegrany, natomiast w negocjacjach integrujących rozwiązanie plasuje się na płaszczyźnie wygrany-wygrany. Ze względu na temat zainteresowania, który dotyczy negocjacji w małżeństwie i rodzinie, uwagę należy skupić tylko na negocjacjach integrujących. Oznacza to, że realizacja zadania lub potrzeby jednego z małżonków nie są tożsame z przegraną drugiego. W negocjacjach kooperacyjnych małżonkowie, chcąc zrealizować osobiste cele, mają równocześnie na uwadze dążenia współmałżonka i szukają rozwiązań zadowalających obie strony. W rozmowach nastawionych na współpracę małżonkowie winni zatem: „skupiać się na wspólnych interesach, a nie różnicach; kierować uwagę na potrzeby i korzyści, a nie stanowiska; wymieniać informacje i poglądy; wynajdywać sposoby na zapewnienie sobie nawzajem korzyści" ${ }^{14}$. Takie podejście do rozmowy wymaga od małżonków wspólnego zaufania, uczciwości i dojrzałości. Dzięki tym cechom strony tworzą sobie warunki do niczym nieskrępowanej i otwartej rozmowy, nie bojąc się poruszyć jakiejś kwestii. Ponadto swobodnie wymieniają się informacjami, w przeciwieństwie do negocjacji konfrontacyjnych, gdzie niektóre informacje się ukrywa, manipuluje, by uzyskać przewagę nad przeciwnikiem.

W negocjacjach nastawionych na współpracę można wyróżnić cztery etapy: określenie problemu, zrozumienie, na czym on polega i ujawnienie interesów, poszukiwanie rozwiązań alternatywnych, ocena i wybór rozwiązania problemu ${ }^{15}$. Określenie i zrozumienie problemu wcale nie jest

13 Zob. R.J. Lewicki, B. Barry, D.M. Saunders, dz. cyt., s. 49-122.

14 Tamże, s. 90.

15 Tamże, s. 94. W sytuacji małżeńskiej strony będą miały interesy powiązania. Polegają one na tym, „że strony cenią swoje powiązania i nie chcą podejmować działań, które by im zaszkodziły. Naturalne interesy powiązania istnieją wtedy, gdy negocjatorzy cenią swoje relacje za samo ich istnienie, ale i przyjemność, jaką czerpią z ich podtrzymywania. Interesy powiązania ujęte instrumentalnie występują wówczas, kiedy obie strony czerpią korzyści z relacji i nie chcą się narażać na ich zepsucie”. Zob. też N. Peeling, Negocjacje. Co dobry negocjator wie, robi i mówi, Warszawa 2010, s. 16-17; K. Bargiel-Matusiewicz, dz. cyt., s. 68-77. 
łatwe, należy bowiem najpierw rozpoznać i nazwać cel (cele) konfliktu czy jest on przedmiotowy, czy dotyczy relacji, tożsamości lub procedury. Pomocą w określeniu problemu może być wymienienie przeszkód, jakie stoją na drodze jego rozwiązania, a także wyszczególnienie tych czynników, dzięki którym się rozpozna, że problem został rozwiązany. Należy pamiętać, że nie można przechodzić do szukania rozwiązań, zanim nie określi się problemu. Ponadto na tym etapie trzeba go zdepersonalizować. Podczas sporu małżonkowie lub członkowie rodziny swoje zachowania i działania postrzegają w pozytywnym świetle, natomiast działania drugiej strony odbierają $\mathrm{w}$ negatywnym, a co za tym idzie, również negatywnie oceniają całą osobę rozmówcy. Tak więc zamiast stwierdzić: „Twój sposób myślenia jest zły, a mój dobry”, należałoby powiedzieć: „Mamy odmienne podejścia do tej kwestii”. Zabezpieczy to przed zamknięciem się drugiej strony, umożliwiając dalszą rozmowę.

Kolejny etap negocjacji to poszukiwanie rozwiązań alternatywnych. Jest to twórczy etap rozmów integrujących. Po określeniu problemu małżonkowie muszą wypracować szereg możliwości jego rozwiązania. Należy mocno zaakcentować fakt, że negocjatorzy winni szukać rozwiązań najłatwiejszych i najmniej kosztownych. Jeśli zawiodą proste środki, dopiero wówczas należy sięgnąć po bardziej kosztowne (wymagające) sposoby rozwiązywania sporu. Przy tym etapie negocjacji pomocne jest stosowanie określonych technik. Jedną z nich jest technika "małych kroków”' Skupia się ona na rozwiązywaniu w pierwszej kolejności spraw drobnych, mniejszej wagi, a dopiero później głównego problemu. Dzięki procedurze rozwiązania drobniejszych sporów małżonkowie widzą, że potrafią dojść do porozumienia, co zachęca ich i daje motywację do podjęcia próby rozwiązania głównego konfliktu. Ponadto dzięki tej technice zacieśniają się między nimi więzi, pogłębiają relacje, zwiększa się satysfakcja z dojścia do porozumienia. Dzięki rozwiązaniu drobniejszych spraw małżonkowie nabierają przekonania, że są w stanie stawić czoła trudniejszym problemom.

${ }^{16}$ K. Bargiel-Matusiewicz, dz. cyt., s. 80.

Niektórzy są przeciwni tej technice, uważając, że należy skupić się przede wszystkim na sprawach istotnych, a dopiero później na tych o mniejszej wadze. Zob. R.B. Adler, L.B. Rosenfeld, R.F. Proctor, Relacje interpersonalne, Poznań 2006, s. 453-454. 
Inna technika polega na zaproponowaniu rekompensaty współmałżonkowi, który zgodził się na ustępstwo. Partner otrzymujący rekompensatę odczytuje ją jako wyraz uznania za akceptację dążeń drugiej strony. Rekompensata nie musi przybierać wymiaru materialnego. Może to być pochwała, czuły gest, wyraz podziwu, docenienie.

Kolejną techniką pomocną w szukaniu rozwiązań jest burza mózgów. Małżonkowie spisują na kartkach swoje propozycje rozwiązania kwestii spornej, a następnie je odczytują. Należy podzielić się wszystkimi pomysłami, nawet jeśli byłyby one abstrakcyjne. Podczas prezentacji koncepcji współmałżonek nie może ich komentować, oceniać ani krytykować.

Czwartym etapem negocjacji integrujących jest ocena i wybór rozwiązań alternatywnych, opracowanych w poprzedniej fazie. Należy tu ograniczyć wachlarz opcji przez dokonanie weryfikacji pod kątem możliwości ich zrealizowania, posiadanych zasobów, umiejętności, poniesienia ewentualnych kosztów. Małżonkowie wspólnie dokonują wyboru strategii rozwiązania problemu i monitorują jego wdrażanie i przebieg.

Przy omawianiu konfliktów małżeńsko-rodzinnych i rozwiązywaniu ich za pomocą negocjacji nie można pominąć kwestii dotyczącej władzy ${ }^{17}$. Przejawiać się ona może w przeforsowywaniu na siłę swoich poglądów, potrzeb, przedsięwzięć, decyzji, kontrolowaniu współmałżonka lub sytuacji. Badania wykazały, że istnieje ponad trzykrotnie większe prawdopodobieństwo, iż konflikty par, które są niezadowolone z związku, będą eskalować i koncentrować się wokół zagadnienia władzy bardziej niż par zadowolonych ${ }^{18}$. Władza może w swojej sile i oddziaływaniu spowodować, że małżonkowie, skupiając się na niej, stracą sprzed oczu przedmiot sporu i możliwość jego rozwiązania. $Z$ tego powodu podczas negocjacji pragnienie władzy należy podporządkować wspólnym celom i zamierzeniom. Można to uczynić przez dzielenie się władzą z partnerem (równoważenie władzy), by poczuł się decydentem, co wprowadzi równowagę między nimi, a także powiększy w nich zdolność budowania relacji,

17 Więcej na temat władzy w konflikcie zob. P.T. Coleman, Konflikt a władza, w: M. Deutsch, P.T. Coleman (red.), Rozwiązywanie konfliktów. Teoria i praktyka, Kraków 2005, s. 108-130.

18 Zob. J. Alberts, G. Driscoll, Containment versus escalation: The trajectory of couples' conversational complaints, „Western Journal of Communication”, 56(1992), s. $394-412$. 
rozwoju wrażliwości i odpowiedzialności za związek. Oboje małżonkowie czują się wtedy ważni i równouprawnieni.

Obok władzy innym elementem często (jeśli nie zawsze) występującym w sytuacji konfliktowej są emocje. Występują one, gdy osoba czuje się zagrożona, atakowana, gdy ma coś do stracenia lub gdy odczuwa coś przykrego. Należy podkreślić, że bardzo często u źródła wybuchu gniewu kryje się strach. Mimo że małżonek może krzyczeć, być impulsywnym, to w rzeczywistości się czegoś boi, choć wcale nie musi być tego świadomy. W takiej sytuacji osoba podczas negocjacji zamiast uwidaczniać swój gniew, np. przez krzyk, winna o nim mówić (nazywać emocje), że czuje w sobie wściekłość, rozdrażnienie, a następnie poszukać jego przyczyn, to znaczy zastanowić się, co mówią te emocje o niej samej, czy jest coś, czego się lęka ${ }^{19}$. Współmałżonek może pomóc, zachęcając do otwartości, tworząc atmosferę bezpieczeństwa. Jeśli nie przyniesie to pożądanego efektu, lepiej będzie odroczyć rozmowę, by zyskać czas na obniżenie emocjonalnego pobudzenia i uzyskanie równowagi, ale z zastrzeżeniem podania terminu powrotu do rozmowy, np. „Wrócimy do rozmowy wieczorem”. Podanie konkretnego terminu jest ważne, by rozmówca nie czuł się zlekceważony, a problem zbagatelizowany.

\section{ZASADY POPRAWNEJ KOMUNIKACJI}

Kolejną kwestią, na którą należy zwrócić uwagę podczas negocjacji małżeńskich lub rodzinnych, jest stosowanie poprawnej komunikacji. Odgrywa ona bardzo ważną rolę i jest niezmiernie przydatna do rozwiązywania konfliktów i poprowadzenia udanych negocjacji. Oczywiście kwestia konstruktywnego porozumiewania się jest obszerna, dlatego na potrzeby niniejszego artykułu zostaną podane tylko jego podstawowe pryncypia ${ }^{20}$.

19 Osoba odczuwająca silne emocje może posłużyć się schematem wypowiedzi: „eśli robisz jakąś czynność A w sytuacji B, to wówczas czuję C”.

${ }^{20}$ Więcej na temat właściwej komunikacji zob. W. Haman, J. Gut, Docenić konflikt. Od walki i manipulacji do wspótpracy, wyd. 3, Gliwice 2008, s. 39-72; C. Sautter, A. Sautter, Gdy opadna maski. Terapia związków, Poznań 2010, s. 211-212; A. Binsztok, Wykorzystanie narzędzi aktywnego stuchania w pracy mediatora, w: A. Binsztok (red.), Sztuka skutecznego prowadzenia mediacji i negocjacji. Zagadnienia psychologiczne i ko- 
Pierwsza zasada poprawnej komunikacji brzmi: nie oceniaj. Często podczas rozmowy małżonkowie oceniają siebie, mówiąc: „Jesteś nieodpowiedzialny”, „Nie można na ciebie liczyć”. Takiego typu zwroty budzą u odbiorcy opór, niechęć i skłaniają do obrony. Ocenę należy zamienić na informację zwrotną wyrażającą uczucie lub oczekiwanie: „Jest mi przykro, że nie dotrzymałeś obietnicy”, „Źle się czuję, gdy mi wciąż przerywasz, kiedy mówię".

Kolejna wskazówka dobrej komunikacji polega na braku uogólniania i interpretowania. Małżonkowie winni się wystrzegać zdań typu: „Ty nigdy...”, „Ty zawsze...”, „Tobie chodzi tylko o...” Współmałżonek, słysząc takie wyrażenie, może czuć się niesprawiedliwie podsumowany, co może wywołać atak lub zawieszenie rozmowy. Interpretacja zaś polega na przypisywaniu znaczenia zachowania partnera według własnego osądu. Często jest to niezgodne ze stanem faktycznym. Interpretacja bazuje na domysłach, które nie zawierają wszystkich informacji o współmałżonku i jego zachowaniu. $Z$ tego powodu należy dopytywać, czy dobrze się rozumie swojego rozmówcę i czy interpretacja jest właściwa. Z interpretacją wiąże się kolejna zasada, a mianowicie mówienie wprost, czyli otwarte wyrażanie swoich potrzeb i uczuć. Zdarza się, że mąż czy żona wychodzą z założenia, że współmałżonek domyśli się, o co im chodzi lub czego potrzebują. Niestety nierzadko jest to wadliwe, gdyż parter nie jest w stanie tego uczynić, co staje się podstawą do wyrzutu: „Ty mnie nie rozumiesz, w ogóle się dla ciebie nie liczę". O wiele lepiej i bezpieczniej dla związku jest mówić wprost o swoich potrzebach i pragnieniach niż liczyć na trafny domysł partnera.

W konstruktywnej rozmowie istotną funkcję pełni koncentracja na tym, co mówi współmałżonek. Dlatego szczególnie ważne rozmowy

munikacyjne, Wrocław 2013, s. 75-83; R.J. Lewicki, B. Barry, D.M. Saunders, dz. cyt., s. 202-207; G. Colombero, Od słów do dialogu. Tysiąc sposobów mówienia i słuchania, Kraków 2005, s. 83-113, 142; M. Mckay, M. Davis, P. Fanning, Sztuka skutecznego porozumiewania się, Gdańsk 2001, s. 150-153; M. Piekara, U. Piekara, Przytul mnie choć na chwilę. Jak być twórczym mężem?, Kraków 2009, s. 110-113; M. Grabowska, W. Grabowski, A. Niemyska, M. Niemyski, M. Wołochowicz, P. Wołochowicz, Zanim wybierzesz... Przygotowanie do życia $w$ rodzinie, Warszawa 1993, s. 62-64; W. Szewczyk, Dlaczego powstaja konflikty i jak je rozwiązywać?, w: W. Szewczyk (red.), Przygotowanie do sakramentu matżeństwa i życia $w$ rodzinie, wyd. 5, Marki 2006, s. 268-270. 
należy prowadzić w sprzyjającym klimacie, bez „rozpraszaczy” takich jak telewizor czy zajęcia domowe. Małżonkowie w skupieniu powinni się słuchać, siedząc obok siebie, a nie prowadzić dialog, zajmując się jednocześnie innymi czynnościami pochłaniającymi ich uwagę.

Nieoceniona pomoc $\mathrm{w}$ rozmowie to parafraza, czyli powtórzenie swoimi słowami tego, co usłyszało się od rozmówcy. Przykłady zwrotów rozpoczynających parafrazę brzmią następująco: „Czy dobrze zrozumiałem, że...”, „Z tego, co mówisz, wynika...”, „O ile cię dobrze zrozumiałem.... Stosując parafrazę, małżonkowie zwiększają prawdopodobieństwo wzajemnego zrozumienia, eliminując ryzyko niewłaściwej interpretacji.

Inną ważną zasadą $w$ rozmowach negocjacyjnych jest trzymanie się jednego tematu. Małżonkowie mają poruszać tylko jedną kwestię będącą przedmiotem konfliktu. Nie powinni wykraczać poza teraźniejszość, wypominając sobie wzajemne uchybienia z przeszłości, lub poruszać kilka kwestii pobocznych. W trzymaniu się jednego tematu przydatne jest narzędzie w postaci klaryfikacji. Niejednokrotnie temat rozmowy jest wielowątkowy i małżonkowie mogą się pogubić, który z nich jest najistotniejszy. Klaryfikacja pomaga zwrócić rozmowę na właściwy tor. Przykładem wypowiedzi klaryfikującej może być następujące sformułowanie: „Do tej pory mówiliśmy o tym... i o tym... Czy możemy wrócić do rozmowy na temat...”, „Wracając jednak do wątku...”.

Niebagatelną rolę w komunikacji małżeńskiej odgrywa również dostrzeganie pozytywów i wzajemne przeproszenie. Pożądane jest, by małżonkowie doceniali swoje dobre zachowania, np. „Dziękuję ci, że nie wybuchnąłeś gniewem, ale powiedziałeś mi o swoich emocjach, o tym, co się teraz w tobie dzieje". Przez pochwałę następuje w partnerze pozytywne wzmocnienie wraz $\mathrm{z}$ docenieniem wysiłku, który włożył w pracę nad sobą ${ }^{21}$. To $\mathrm{z}$ kolei zachęca do pogłębienia dialogu i zbliżenia emo-

${ }^{21}$ Warto zauważyć, że zmianę podejścia do rozwiązania konfliktów można przeprowadzić na trzy sposoby. Pierwszy polega na zmianie drugiej strony, to znaczy małżonek stara się „naprawić” swojego partnera, ukazując, że przyczyna konfliktu tkwi w nim i w jego zachowaniu. Takie podejście najczęściej spotyka się z oporem i zaostrza napiętą sytuację. Druga możliwość polega na zmianie warunków konfliktu, czyli na dostarczeniu brakujących zasobów, np. czasu, sprzyjających okoliczności do rozmowy. Trzecia droga skupia się na zmianie własnej komunikacji i spostrzegania konfliktu oraz osoby współmałżonka. Wymaga to najpierw włożenia wysiłku w zmianę samego siebie 
cjonalnego rozmówców. Podobnie oddziałuje przeproszenie partnera za swoje zachowanie lub pogwałcenie zasad poprawnej komunikacji. W ten sposób wyrażony jest żal, który jest informacją dla współmałżonka, że ten jest ważny dla rozmówcy.

Podsumowując powyższe rozważania, należy stwierdzić, że warunkiem prowadzenia negocjacji integrujących jest przychylne nastawienie rozmówców do poszukiwania rozwiązań. Ponadto muszą występować następujące czynniki: posiadanie wspólnego celu (np. trwałość małżeństwa, miłość), wiara we własne umiejętności rozwiązywania problemów, szacunek wobec stanowiska współmałżonka, zaangażowanie we wspólne szukanie rozwiązań, a nie rywalizacja, darzenie się zaufaniem (bo nieufność przeszkadza w kooperacji), dojrzałość osobowa, poprawna komunikacja. Małżonkowie w negocjacjach powinni wyrażać i uwzględniać swoje potrzeby, rozpoznawać podobieństwa, uznawać i akceptować różnice. Negocjacje stają się także sposobem uzyskania informacji na temat współmałżonka, co prowadzi do wzrostu współzależności i bliskości.

Pozytywnie rozwiązany konflikt małżeński lub rodzinny dzięki negocjacjom ukazuje, że sama sytuacja konfliktowa nie zawsze jest rzeczywistością negatywną, mimo że często przypisuje się jej ujemne konotacje. Dobrze przeżyty konflikt jest czymś wartościowym i produktywnym. Stymuluje on zmiany w samej jednostce i w relacjach interpersonalnych, co prowadzi do osobistego rozwoju i progresu w związku. Dzięki rozwiązanemu przez negocjacje konfliktowi małżonkowie poszerzają paletę posiadanych zasobów niezbędnych do satysfakcjonującej koegzystencji, rozwijają swoją twórczość w szukaniu rozwiązań zadowalających obie strony i lepiej siebie poznają, zacieśniając więzi emocjonalne.

Dana zauważa, że „nie mieć konfliktów to znaczy nie żyć” ${ }^{22}$. Zatem należy podkreślić, że konflikt jest zjawiskiem naturalnym w kontaktach międzyludzkich, a sposób jego rozwiązania ma realne przełożenie na jakość i przebieg relacji między osobami. Niemniej małżonkowie muszą uznać wspólną odpowiedzialność za rozwiązanie konfliktu²3. Jeśli tylko

zamiast wymuszania zmiany drugiej strony. Dzięki negocjacjom, będącym wyrazem troski o relacje, zadanie to jest jak najbardziej osiągalne, choć niełatwe.

22 D. Dana, Rozwiązywanie konfliktów, Warszawa 1993, s. 34.

${ }^{23}$ Zob. D. Krok, Strategie rozwiązywania konfliktów $w$ systemie rodzinnym, „Roczniki teologiczne”, t. LIV, z. 10(2007), s. 134. 
jedna strona będzie dążyć do rozwiązania problemu, stosując podane zasady, a druga będzie stawiała opór lub będzie obwiniać współmałżonka, to negocjacje mogą nie przynieść pozytywnego rezultatu. Dopiero wspólne zaangażowanie w rozwiązanie konfliktu i to w sposób satysfakcjonujący obie strony przyczynia się do szczęścia w małżeństwie i rodzinie.

Streszczenie. Konflikt jest zjawiskiem, które występuje w każdej grupie społecznej. Nie omija on również małżeństwa i rodziny. W życiu małżeńsko-rodzinnym jest on o tyle istotny, że ze względu na silne relacje emocjonalne może być przyczyną powstawania zranień, zniszczenia więzi uczuciowych oraz zaburzeń komunikacji wewnątrzrodzinnej między osobami. Skuteczną pomocą w rozwiązywaniu konfliktów powstających między małżonkami bądź członkami rodziny mogą być negocjacje.

Niniejszy artykuł dzieli się na dwie części. Pierwsza przybliża naturę konfliktu, jego cele i strategie reagowania w sytuacji konfliktowej. Druga zaś opisuje, czym są negocjacje, $\mathrm{z}$ jakich etapów się składają, w jaki sposób je przeprowadzić i na co zwrócić uwagę podczas ich trwania. Ze względu na ścisłe powiązanie negocjacji z umiejętnością prowadzenia rozmów przybliżone zostały także zasady poprawnej komunikacji interpersonalnej.

Słowa kluczowe: małżeństwo; rodzina; konflikt; negocjacje; komunikacja; porozumienie.

Summary. Negotiations as a strategy to respond in the marriage and family conflict situation. Conflict is a phenomenon, which occurs in every social group. It also does not avoid marriage and family. In life, marriage and family it is all the more significant because due to the strong emotional relationships might be the reason of struggles and destructions of emotional ties and intrafamilial communication disorders among persons. Effective method to resolve conflicts arising between family members can be negotiations.

The article is divided into two parts. The first part brings the nature of the conflict, its objectives and strategies to respond in the conflict situation. The second one describes what the negotiation is, from which parts it is composed. Due to the close linkages with the ability to conduct interviews, are also approximate the principles of better interpersonal communication.

Keywords: marriage; family; conflict; negotiation; communication; agreement. 